\title{
Argentina and the global capital roller coaster of the 1990 s
}

\author{
Argentina e a montanha-russa \\ do capital global dos anos 1990
}

JAN PETER WOGART*

RESUMO: Este ensaio analisa o experimento argentino "currency board" durante a década de 1990, tanto do ponto de vista teórico quanto histórico. Descobriu que as tentativas anteriores de controlar a inflação com uma taxa de câmbio quase fixa em um ambiente altamente politizado deveriam ter sido uma lição a ser ouvida. Ao detalhar as várias deficiências das políticas econômicas domésticas, um amplo espaço é dedicado a examinar os mercados de capitais internacionais e seu impacto no programa argentino. Além disso, sustenta-se que o ambiente político argentino, cuja estabilidade foi crucial para o sucesso nos primeiros anos, deteriorou-se tanto depois de 1996 que contribuiu significativamente para o colapso do programa econômico e do próprio sistema. O ensaio conclui com uma breve consideração das políticas econômicas chilenas, que foram caracterizadas por um grande grau de pragmatismo e prudência e, consequentemente, conseguiram escapar do terrível destino de seu vizinho.

PALAVRAS-CHAVE: Fluxos internacionais de capital e instabilidade macroeconômica; endividamento externo argentino; políticas argentinas de taxa de câmbio.

ABSTRACT: This essay analyzes the Argentine "currency board" experiment during the 1990s, both from a theoretical and historical point of view. It finds that earlier failed attempts to control inflation with a quasi-fixed exchange rate in a highly politicized environment should have been a lesson to heed. While detailing the various shortcomings of the domestic economic policies, ample space is devoted to ex- amine the gyrating international capital markets and their impact on the Argentine program. Moreover, it is maintained that the Argentine political environment, the stability of which was crucial for success in the early years, deteriorated to such an extent after 1996 that it significantly contributed to the breakdown of the economic program and the system itself. The essay concludes with a short consideration of the Chilean economic policies, which were characterized by a great degree of pragmatism and prudence and consequently succeeded to escape the dire fate of its neighbor.

KEYWORDS: International capital flows and macroeconomic instability; Argentine external indebtedness; Argentina fixed exchange rate polices.

JEL Classification: E31/32; E42/44: E61/63.

\footnotetext{
* Senior research fellow at the Deutsche Uebersee Institut (German Oversees Institute), Hamburg/Germany. E-mail: peterwogart@hotmail.com. Submitted: April 2003; accepted: May 2003.
} 
Argentina has had a long and horrifying history of political and economic instability in the 20th century, most of which has been documented by social scientists for many years. (Mallon and Sourouille 1975, Ferrer 1979, Diaz-Alejandro 1981). At the macro-economic level the major issue has been to break the "stopgo" cycle of development and find the appropriate fiscal, monetary and industrial policies, which would build trust of the Argentine citizens towards their politicians and their economic and social policy makers.

After having accumulated large foreign exchange reserves during World War II, populist public policies led to monetized fiscal deficits, high rates of inflation, and large balance of payments deficits. When attacked by shock treatments, output and employment were reduced to levels which became politically destabilizing. As restrictive fiscal and monetary policies were relaxed, inflation raised its head again and with it balance-of-payments and external debt problems, requiring a new round of devaluation and stabilization measures.

Although taking increasingly structural factors into consideration in the 1970s and 1980s, stabilization efforts did not fare much better. Reduced inflation had to be bought by reduced output and employment growth, if not stagnation and recession. A serious two phase program in the late 1970s to bring down inflation first and then use a combined liberalization-cum stabilization effort through a predetermined moving peg combined with financial and tariff reform was showing some results, before it was abandoned in 1981 as a consequence of fiscal and political weakness of the then ruling military government (Wogart, 1983).

In that climate of instability, public distrust and cynicism spread, and transaction based on expectations of rising prices and devaluation of the local currency became common. During Latin America's "lost decade" of the 1980s, inflation accelerated no matter which policy was applied. As a matter of fact, the inflation rate remainde only once below the $100 \%$ level, and per capita incomes declined during most years.

When President Menem took over by mid-1989, there was an almost complete loss of confidence of the public in any political system much less any politician to solve Argentina's economic problems. A great number of hastily conceived crisis plans and structural reform measures led to nowhere. As the monthly inflation reached 27\% (an annualized rate of 1660\%) in February of 1991 , society seemed ready for some drastic measures. They finally came in the form of a radical convertibility plan, designed by the Economic Minister Domingo Cavallo, who proposed to permanently and legally peg the exchange rate of the Argentine currency, the peso, one for one to the US dollar.

After briefly discussing the major requirements of the "currency board" exchange rate regime, this essay will analyze the major policies and factors, which shaped the fate of the Argentine economy in a context of a world awash in cap- 
ital. An attempt will be made to evaluate the internal and external factors, which determined the early successes, the later problems, and the final collapse of that policy framework. Limited space will be allocated to the treatment of various financial crises which swept through the industrializing countries in East and West, followed by a closer examination of the outcomes of the similar but less stringent stabilizationcum-liberalization programs of Brazil and Mexico, and Chile.

\section{THE CONVERTIBILITY PLAN AND THE CONSTRAINTS OF THE CURRENCY BOARD EXPERIMENT}

To use exchange rate policy as an anchor in inflation prone economies has become the rule rather than the exception in a number of other Latin American economies in the 1990s, among which Brazil and Mexico were the more important ones. However, with the establishment of a currency board and an exchange rate fixed by law, Argentine policy makers went one step further with the aim to curb inflationary expectations once and for all.

The potential advantages of a currency board are well known. First, it deactivates monetary policies, substituting automatic rules for uncertain policy action. Strictly applied, the approach makes it difficult if not impossible for deficit ridden states to be financed by monetary emission, since money supply depends on the inflows and outflows of foreign exchange. Secondly, it is credited with being able to achieve both lower inflation and higher output, once the program is fully implemented.

That approach appeared to be a better alternative to stabilize a high inflationary economy than the orthodox fiscal and monetary austerity programs, which had often been used and failed in the past. Instead of drastic cuts in public expenditures, which mostly hurt the poor, and restricted credit, hurting business investment, the adjustment takes place through the balance of payments, mainly through significant capital inflows and outflows. Of course there is a hitch. The required conditions for the full functioning of this mechanism are free trade, open capital and flexible labor markets, or at least a determined movement towards those goals.

The outlook for fulfilling those major conditions was mixed. Capital markets could be opened quickly, as had been done in the past. Freeing trade and attacking some bastions of protected industries required more courage. As to the flexible labor market, Argentine unions were known to be strong. Wage flexibility had not been the hallmark of earlier experiences. Nevertheless, the increasing integration of Argentina's industrial sector into the global economy made it likely that wage determination would become more flexible and market determined. As to functional finance, hope was pinned on that strong political leadership assisted by competent and experienced fiscal managers, who 
would accomplish the task to achieve surpluses during the good years in order to act as stabilizing force during years of hardship.

Just to make sure that the currency board scheme would not become too stringent, the Convertibility Plan left a few doors open for policy action by Congress and the Central Bank. Among them was the possibility for the legislative body to alter the exchange rate, cumbersome indeed but in times of crisis considered possible. In addition, the Central Bank was allowed to sterilize foreign exchange reserves, once they had passed a critical minimum. It was determined to have two thirds rather than $100 \%$ of the money supply be backed by foreign exchange, and there was also a provision to have a $10 \%$ limit on increases of money supply to be backed by government securities. To help the Central Bank being the lender of last resort in times of crisis it was determined to open up the domestic banking system to more foreign banks, with the head offices of the local branches being asked to provide emergency liquidity for a Contingent Repurchasing Facility.

\section{IMPLEMENTATION OF MAJOR POLICY REFORMS AND EARLY SUCCESSES}

The immediate implementation of the Convertibility Plan was made possible through two conditions, which the Argentine economy fulfilled in 1991. First, the foreign exchange required to back the money base was modest, since inflation had greatly diminished the demand for peso-denominated real money balances. With people increasingly going into dollars and/or real assets, the monetary base had been reduced to 4.2\% of GDP in 1991 .

Secondly, serious fiscal efforts were undertaken. Recognizing the severity of the crisis, the President backed far going fiscal reforms by his economic minister, who was able to increase public sector revenues and contain current expenditures. The tax base was broadened and far going privatizations of deficit ridden public enterprises were carried out. The public sector deficit was turned into a surplus between 1991 and 1993/94. As Table 1 indicates, current revenue rose from 11 to nearly $15 \%$ of GDP, with expenditures just being below those amounts for 1992/93 but then surpassing them for $2 \%$ and more for the second half of the 1990s.

Table 1 also shows that the private sector responded rapidly by investing in a style not seen for many decades. Within three years, total investment raised its share in GDP from 15 to $20 \%, 90 \%$ of which came from the private sector. Foreign investment also participated increasingly, with major disbursement taking place during the second part of the 1990s. 
Table 1: Key Economic Indicators: 1991-98

\begin{tabular}{lcccccccc}
\hline \multicolumn{1}{c}{ Indicator } & 1991 & 1992 & 1993 & 1994 & 1995 & 1996 & 1997 & 1998 \\
\hline $\begin{array}{l}\text { Central Government Current } \\
\text { Revenues (excl. grants, as \% of GDP) }\end{array}$ & 11.2 & 12.3 & 15.1 & 14.9 & 14.0 & 13.0 & 13.6 & 14.1 \\
\hline Current Expenditures (as \% of GDP) & 11.4 & 12.0 & 14.6 & 15.2 & 15.8 & 15.4 & 15.3 & 16.1 \\
\hline GDP growth (annual in \%) & 12.7 & 11.9 & 5.9 & 5.8 & -2.8 & 5.5 & 8.1 & 3.9 \\
\hline GNP per capita growth & 11.3 & 10.5 & 4.5 & 4.4 & -4.2 & 4.2 & 6.7 & 2.8 \\
\hline $\begin{array}{l}\text { Inflation (changes in consumer price } \\
\text { index in \%) }\end{array}$ & 171.7 & 24.9 & 10.6 & 4.2 & 3.4 & 0.2 & 0.5 & 0.9 \\
\hline $\begin{array}{l}\text { Gross domestic investment } \\
\text { (as \% of GDP) }\end{array}$ & 14.5 & 16.7 & 19.1 & 19.9 & 17.9 & 18.1 & 19.4 & 19.9 \\
\hline $\begin{array}{l}\text { Foreign direct investment } \\
\text { (net, in \% of GDI) }\end{array}$ & 8.8 & 11.5 & 61. & 6.7 & 11.4 & 13.2 & 14.3 & 10.4 \\
\hline Exports (as \% of GDP) & 7.7 & 6.6 & 7.0 & 7.6 & 9.7 & 10.5 & 10.6 & 10.4 \\
\hline Imports (as \% of GDP) & 6.1 & 8.1 & 9.3 & 10.6 & 10.1 & 11.1 & 12.7 & 12.9 \\
\hline
\end{tabular}

Source: IBRD, Argentina: Country Assistance Evaluation, Washington, 2000.

The major macro data for income growth and inflation containment showed similar positive developments, fulfilling earlier expectations that the currency board approach was working. Per capita income increased by over $10 \%$ in the first two years and $4.5 \%$ in the following two. At the same time, the rate of inflation fell from a whopping $172 \%$ in 1991 to $25 \%$ in 1992 and to 11 and $4 \%$ in 1993/94 respectively.

At last Argentina had found success in being able to pursue a simple and effective policy framework. Of course, the external economic situation was highly favorable, with the US economy starting its decade long expansion and international capital flows increasing to levels which were beyond the most optimistic expectations. In the case of Latin America it net capital inflows rose from $\$ 9.6$ billion in 1989 to $\$ 18.4$ billion in 1990, \$36 billion in 1991, and $\$ 45$ billion in 1992 (Kuczynski, 1992). The good times had arrived, or so it seemed.

\section{THE MEXICAN CRISIS AND THE DANGER OF CONTAGION IN THE MID-1990s}

A combined stabilization-cum-liberalization program had already been attempted in Mexico in 1989. While less stringent, the strategy of lowering inflation through pegging the exchange rate and open up capital markets as well as gradually liberalizing markets for goods and services resulted in similar encouraging results in that country's economy. Inflation dropped from an average of 
$70 \%$ in the 1980 s to less than $20 \%$ in the early 1990 s. Per capita incomes, which had fallen before the stabilization effort, recuperated right afterwards, its growth averaging $\%$ between 1990 and 1995 .

Predictably enough, that strategy had its immediate impact on the balance of payments. The import liberalization policies led to rapidly increasing trade and current account deficits, which were however easily financed by external capital, drawn in by the low risk scenario of a fixed exchange rate regime at home and a "Washington Consensus" abroad that would make the multilateral institutions come to the rescue in case those liberalization efforts would face a balance of payment crisis.

The major developments of the trade, current account, and capital balance of the three major economies in Latin American countries before and after the stabilization-cum-liberalization efforts are highlighted in Table 2. They show the expected results. Mexico, Argentina and Brazil became one more time the champions of importing economies, with annual growth rates averaging between 14 and $34 \%$ between 1990 and 1996 . The resulting current account deficits, which would have been considered of being non sustainable only a decade earlier, were now considered perfectly manageable in the light of seemingly plentiful foreign capital, which considered developments in the country's balance-of-current accounts as secondary to the actual and future capital balance.

Table 2: Stabilization and Liberalization and their Effects on the Balance-of-Payments in Mexico, Argentina and Brazil (Billions of US\$)

\begin{tabular}{|c|c|c|c|c|c|c|c|}
\hline \multicolumn{2}{|r|}{ Country } & \multicolumn{2}{|c|}{ Trade Balance } & \multicolumn{4}{|c|}{ Current Account } \\
\hline \multicolumn{2}{|r|}{$\begin{array}{l}\text { Year before } \\
\text { Program }\end{array}$} & \multicolumn{2}{|c|}{$\begin{array}{l}3 \text { years following } \\
\text { Program }\end{array}$} & $\begin{array}{l}\text { Year before } \\
\text { Program }\end{array}$ & \multicolumn{3}{|c|}{$\begin{array}{l}3 \text { Years following } \\
\text { Program }\end{array}$} \\
\hline \multicolumn{2}{|r|}{ (1987) } & \multicolumn{2}{|c|}{ (1990-1992) } & (1987) & \multicolumn{3}{|c|}{ (1990-1992) } \\
\hline Mexico & 8.8 & $-0.9 \quad-7.3$ & -15.9 & 4.2 & -7.5 & -14.9 & -24.4 \\
\hline \multicolumn{2}{|r|}{ (1990) } & \multicolumn{2}{|c|}{ (1992-1994) } & (1990) & \multicolumn{3}{|c|}{ (1992-94) } \\
\hline \multicolumn{2}{|l|}{ Argentina } & $-1.4 \quad-2.4$ & -4.1 & 4.6 & -5.5 & -8.0 & -10.9 \\
\hline \multicolumn{2}{|r|}{ (1993) } & \multicolumn{2}{|c|}{ (1995-1997) } & (1993) & \multicolumn{3}{|c|}{ (1995-97) } \\
\hline & Brazil 14.3 & $\begin{array}{ll}-3.2 & -5.6\end{array}$ & -8.4 & 0.02 & -18.1 & -23.6 & -33.8 \\
\hline
\end{tabular}

Source: IMF, International Financial Statistics Yearbook 1999, Washington, 2000.

Residents apparently thought differently and started to buy dollars in late 1994 (IMF, 1995). As economics and politics joined hands, the large current account deficit led to capital flight, while the authorities attempted to defend the exchange rate band with the sale of reserves and short term convertible bonds. With the confidence of investors being shaken by the turmoil of an election year, characterized by charges of massive corruption at highest places and the killing of the presidential candidate starting in 1995, it was only a question of time 
when the exchange rate had to be freed and Mexico had to go to the IMF for a massive support program ${ }^{1}$.

As investors looked for similar precarious patterns of rapidly rising external debt and current account deficits around the world, analysis and action concentrated on Latin America, first and foremost on Argentina, whose trade and current account deficits had opened up in the mid 1990s. Improvements in exports, which rose by an annual rate of $12 \%$ between 1990 and 1995, were dwarfed by import growing at 34\% p.a., making Argentina the champion of imports in the 1990s.

Predictably, capital flows reversed and the country lost a third of its foreign exchange reserves within the first three months of 1995. In addition, a banking crisis erupted, which the authorities were able to contain with the help of the IMF and the World Bank. On the real side of the economy, the import drive was slowed down considerably, as the automatic mechanism of a reduced money supply led to less domestic credit and with it reduced aggregate demand. As demand for imports and demand on the domestic front slowed down, GDP fell by $2.8 \%$ in 1995 . While the Tequila crisis could have easily become a " $\mathrm{La}$ Plata" crisis, this time politics helped. Different from the Mexican case, the early record of the Menem government had been strong enough to secure an easy re-election. That provided the base for continuity of the economic policy framework in the years to come.

Armed with the evidence that the policy makers had things under control in the domestic economy, i.e. successfully controlling public sector deficits, and were also able to quickly react on the external front, creditors were willing to give Argentina the benefit of the doubt and extended long term loans by another US\$13 billion in 1995 and \$11 billion in 1996. In addition, foreign direct investment just started to translate major decisions into disbursement. Foreign investment's share in gross domestic investment rose from 6.7 to $11.4 \%$, with significant amounts of money being invested in banking, privatized infrastructure and the automobile industry.

Indeed, in the years following the "Tequila Crisis" the Argentine economy took off, as if nothing had happened. Investment and output growth accelerating again to respectable levels, with per capita income rising from $\$ 10,500$ to $\$ 11,700$ within three years. At the same time inflation was brought down further under control, increasing by less than 1\% during the 1996-98 period. Concurrently, even poverty had been reduced, with the poverty rate falling from over $30 \%$ in $1990 / 91$ to $22 \%$ in 1995/96 (World Bank, 2000a). The only bleak spot

\footnotetext{
${ }^{1}$ There were other serious political disturbances in Mexico during 1994, beginning with rebels seizing six town in Chiapas in January and ending with the killing of PRI Secretary General in September and renewed fighting in Chiapas in December.
} 
in the economic picture was the rather rapid rise in unemployment, hitting $17.5 \%$ in $1995 / 96$, after having been under $7 \%$ at the beginning of the 1990 s.

The latter development was considered by the policy makers to be a temporary phenomenon of the adjustment process, which would ultimately be solved by the emergence of a modern, efficient and rapidly growing economy. After all, did not the amazing job creating machine of the US economy during the 1990s serve as a perfect example of what was in stake for the Southern Cone economies, if they would just dismantle their inefficient public enterprises and get rid of those branches of industry which had continued to survive only because of the various protection measures?

Critics, of course, looked at the unemployment differently. They pointed towards earlier experiments with the stabilization-cum liberalization efforts and noted that Argentina was continuing its path towards a weakening of its industrial depth if not the country's slow but sure "de-industrialization" (Messner, 1996). Instead of getting away from a concentration on raw materials and its processing industries, Argentina was back to specialize in sectors which kept that country critically dependent on both, the simple labor intensive and the more sophisticated imports to be financed by slow growing exports. In short, for the critics the model was not sustainable, an issue to which we will come back to at the end of the essay.

\section{THE STORM CLOUDS MOVE FROM WEST} TO EAST AND BACK TO ARGENTGINA

After the Mexican crisis, the governments of the OECD countries proposed a number of reforms to both prevent future financial crises and cope more effectively with the ones which were to occur ${ }^{2}$. Those efforts had little to offer when it came to the Asian crisis and again failed to foresee the worldwide implications of that turmoil. As Argentina survived the first contagion attack, other emerging economies saw their development also threatened by rapidly shifting capital flows.

The financial crises in South-East Asia, Eastern Europe and Brazil have been analyzed in a background paper (Wogart, 2003). They provided two major blows to Argentina. First, they turned international investors' form optimistic providers of ample capital funds into pessimists, withdrawing unilaterally large parts of their financial assets from emerging economies. Secondly, by ushering devaluations, particularly in Brazil, it made the fixed Argentine peso ever more expensive and difficult to compete.

\footnotetext{
2 Those efforts got an official name in April 1998, when the then US Secretary of the Treasury spoke of the need for strengthening the "architecture" of the international financial system.
} 
Having to cope with the uncertain international situation was not enough for the Argentine economic policy makers. The end of the second term of President Menem and with it the need to elect a new President became the decisive element in 1999 and brought in two contrary elements, which are reflected in the amazing mix of economic data. First, the uncertain future led Argentines to cut back on expenditures and shift their assets abroad and/or under their mattresses. After all, wouldn't it be possible for a new President to follow the example of Brazil and devalue the Peso? Secondly, election years are heavy spending years, as witnessed by the jump in public expenditures and heavy borrowing of the government. Again, part of that money seems to have gone out of the country too, as the $\$ 5.5$ billion in the "Errors and Omissions" section of Argentina's balance-of-payments suggests.

In spite of substantial increases in direct foreign investments, portfolio investment sagged in 1997/8, as the Asian crisis and the Russian default heightened the risk averseness of the international investors in emerging stock and bond markets. However, confidence erosion in 1999 was at least partly home made, as investors transferred a whopping $\$ 10$ billion abroad. Had it not been for the extra-ordinary high disbursement of direct private investment of $\$ 22.7$ billion, Argentina's balance of payments would have been in serious trouble 1999. ${ }^{3}$

While the declining exports were linked to exogenous factors, cutbacks in domestic investment and consumption led to significant contraction of output in nearly all sectors of the economy in 1999. Worst hit were construction and the manufacturing sector, the output of which respectively declined by 8.3 and $7.7 \%$ in 1999 and a further 9.3 and $3.8 \%$ in 2000 . Real gross fixed domestic investment showed an even more dismal picture, as it declined by $13 \%$ and $7 \%$ during the same two years. Apparently domestic investors had a serious confidence problem.

Exports had held up relatively well until 1998, in spite of decreasing terms of trade, and the increased pressure of a renewed campaign by East Asian exporters to recoup markets lost during the crisis years of 1997/98. However, the blow of the Brazilian devaluation had Argentine exports fall for the first time in the decade, and while those exports recuperated again to 1998 levels in 2000, further expansion remained difficult, as demand from other Latin and world markets started to slow down. The appreciation of the Dollar vis-à-vis the Euro did not help either, but since exports made up just over $10 \%$ of the Argentine economy, a ten percent drop should have not reduced output by more than $1 \%$.

The sluggish developments in the private sector led to a decline of tax revenues of 500 million Pesos. At the same time, current expenditures leaped by near-

\footnotetext{
3 The large foreign investment was caused by the sale of Argentina's national oil company to foreign investors, some of which had owned stock earlier on. As a consequence, part of the transaction was a shift from portfolio to direct foreign investment.
} 
ly 3 billion Pesos, leading to a deficit of 7.3 billion Pesos, or $2.6 \%$ of GDP, nearly twice the earlier deficits. A very similar problem developed in the provinces, whose deficits accelerated quickly from 1.4 over 2.5 to 4.5 billion Pesos between 1997 and 1999. Taken together, Argentina's public sectors required 11.8 billion Pesos or 4.2 of GDP to cover their deficits in 1999, nearly twice the 6.7 billion in 1998 and 6 billion in 1997 (2.2. and 2.1\% of GDP respectively).

A good part of that deficit had to be covered by domestic sources, including the revenues from privatization, which provided a hefty 2.6 billion Pesos. Besides rolling over past accumulated public sector debt, the domestic financial institutions took on another 2.7 billion Pesos, and some additional funds were used from the pension funds. With barely half coming from the domestic economy, Argentina was getting more heavily involved in the international markets and issued over 13.1 billion dollars in public sector bonds. In addition, both the World Bank and the IDB provided financial support of $\$ 2.35$ billion through adjustment operations (SAL and Special Repurchase Facility Support and Policy Based Guarantee Operation).

Net contributions from bi-lateral sources, commercial banks, and even the IMF were negative in 1999, i.e. repayments of debt surpassed disbursements of those three groups by $\$ 2.4$ billion. In total, net borrowings came to $\$ 5.4$ billion, expanding the external debt of Argentina to $\$ 146$ billion. As Argentina raised its official indebtedness rapidly, accumulating more than double the amount with which it started at the beginning of the program, it provided a pattern quite similar to the ones to be observed in the "debt-cum-growth efforts" of Brazil and Mexico as shown in Table 3.

Table 3: External Debts of the Three Major Latin American Economies in the 90s (Billions of US\$)

\begin{tabular}{ccccccc}
\hline Year & Mexico & $\begin{array}{c}\text { Brazil } \\
\text { Total }\end{array}$ & Argentina & \% of GDP & \multicolumn{2}{c}{$\begin{array}{c}\text { Debt Service } \\
\text { In Bill \$ }\end{array}$} \\
\hline 1991 & 116.6 & 123.9 & 61.3 & 23.1 & 7.2 & 37.0 \\
1992 & 117.5 & 135.9 & 62.8 & 26.8 & 5.4 & 31.6 \\
1993 & 131.7 & 145.7 & 72.5 & 27.7 & 6.4 & 34.9 \\
1994 & 142.2 & 148.3 & 85.7 & 30.9 & 7.6 & 36.0 \\
1995 & 169.7 & 159.3 & 98.5 & 39.5 & 10.2 & 34.7 \\
1996 & 163.5 & 179.9 & 111.6 & 41.0 & 15.7 & 47.6 \\
1997 & 153.0 & 200.0 & 125.1 & 42.7 & 17.3 & 47.4 \\
1998 & 161.2 & 243.2 & 140.6 & 47.0 & 21.1 & 56.7 \\
1999 & 161.5 & 240.0 & 146.1 & $51.6(73.7)(\mathrm{a})$ & 24.6 & 72.6 \\
Increase & & & & & & \\
$1991-99$ & 44.9 & 116.1 & 84.8 & 29.6 (b) & 17.4 & 34.8 (b) \\
in \% & 38.5 & 93.7 & 136.5 & 44.4 (c) & 24.2 & 51.8 (c) \\
\hline
\end{tabular}

Source: IBRD, World Bank Debt Tables, Washington, 2001.

(a) Total External debt over "adjusted" GDP; (b) 91-95 average; (c) 95-99 average. 
Among the three big spenders, Argentina remained the smallest debtor. However, while Mexico curbed external debt after 1995, Argentine debt rose by $50 \%$ during that time and registered an increase of $136.5 \%$ for the decade as a whole. One can argue to what extent an external debt/GDP ratio, preferred by financial sector analyst, is a relevant indicator for the sustainability of external debt accumulation. While 50\% may seem reasonable for a European economy, it may not do for Latin America. If in addition, one makes adjustments for the calculated overvaluation of the currency (we took $30 \%$ here for 1999 ), the adjusted $73 \%$ should have given rise to serious concerns. For the traditional school of observers, it was clear that the debt service ratio registered increasingly unsustainable levels. As Table 3 shows, that ratio shot up from an average of 35\% between 1991 and 1995, to nearly 50\% in 1996/1997 and to over $70 \%$ at the end of the decade.

\section{THE END GAME}

The problems the incoming President de la Rua faced were daunting. In addition to his political problems of governing with a Congress dominated by the opposition party, he was caught between a rock and a hard place, as he had to attempt to revive the economy with cutbacks in the public deficit and borrowing. Furthermore, disagreements within the ruling coalition led to the resignation of the Vice President in October of 2000, providing a new shock of confidence and increased problems in tapping external financial markets.

As investment continued to decrease, the recovery of exports and some minor rise in consumption were insufficient to revive the economy. Unemployment remained high, and dissatisfaction with the strict economic regime increased. Continued problems with revenue collection led to a revision of the fiscal deficit, which was expected not to surpass $1.5 \%$ but was adjusted to $2.3 \%$ of GDP. As the access to external finance became more difficult and expensive, the government decided to tap the domestic market, with the result of increasing interest rates and crowding out potential private borrowers.

One more time, the multinational institutions came to the rescue. To avert a liquidity crisis, the government agreed with the IMF on an adjustment program in late 2000 , providing $\$ 40$ billion in emergency financing. The package was designed to give the Argentine policy makers time to address the continuing fiscal problems, carry out structural reforms, and - most importantly restore confidence of investors and consumers. Different from earlier crisis scenarios, the external economic conditions were favorable in 2000/2001, exhibiting moderate but sustained growth of world output and trade, low international interest rates and improving terms of trade for Argentina.

The government program agreed with the IMF included the implementa- 
tion of the Fiscal Sustainability Law and the fiscal pact with the provinces, which targeted a zero fiscal balance by 2005 . However, as the revenue shortfall persisted and the economy continued to stagnate, The government was able to convince the IMF officials that a too restrictive fiscal policy would do further damage to the already weakened economy and eventually contribute to possibly destroy the whole "stabilization-cum-growth" program.

Hoping for the old magic to shine again, the President called for the "father" of the program, Domingo Cavallo, to rescue the fortunes of the sagging Argentine economy in April of 2001. One issue the "new" economic minister attempted to remedy was to get off the "hard" peg by linking the Argentine peso to a 50/50 dollar/ euro basket in mid-2001, adjusting for the dollar appreciation against the euro by over $15 \%$ in the late 1990 s. The judgment of the market was too little, too late.

He also reduced the liquidity reserves of the commercial banks against the opposition of the then Central Bank President, and finally initiated a large swap of Argentine government debt, which was to reduce short and medium term interest and amortization payments. However, none of those actions amused the ever more critical private investors, who were also alarmed that all of those decisions seemed to have been taken almost single handedly by the Economic Minister, without even consulting with the closest staff (Mussa, 2000).

At the home front, matters turned from bad to worse in the third quarter of 2001 , as investment fell by another $18 \%$, leading to a shrinking output of $5 \%$. Rising unemployment, which was climbing from $15 \%$ in late 2000 to $18.3 \%$ in October 2001, brought more social unrest and with it more capital flight. While exports held up well, and foreign support in terms of direct foreign investment ( $\$ 4$ billion) and multiand bilateral aid ( $\$ 11.5$ billion) continued to be strong, net outflows to commercial banks, resident lending abroad and other private creditors accumulated to $\$ 12.6$ billion. On top of that the unaccounted "Errors and Omissions" registered an additional $\$ 8.3$ billion.

Although the IMF provided still another support line of US\$6 billion in September of 2001, massive outflows of capital made it only too clear that the time had come to prepare for an orderly restructuring program of the ballooning debt combined with a more flexible fiscal, monetary and exchange rate program. As the daily Eurobond Option Adjusted spread climbed from 2000 to 4000 points, Argentina's ability to raise new funds became extremely limited and expensive.

In a desperate attempt to slow down the hemorrhage of capital flight, the government issued a decree to severely limit the depositors' ability to withdraw money from their accounts in mid December. What became called the "corallito" initiated widespread protests of Argentine's middle class or what 
had remained of it. Protesting with pots and pans in the streets of Buenos Aires and other cities in the interior, soon turning into violent fights and looting, led first to the resignation of the Economic Minister, then to the President himself, and finally to the abdication of Argentina's currency board experiment.

After a frantic search for viable candidates to lead the country, which went through five failed attempts, the ex governor of the Province of Buenos Aires, Eduardo Duhalde assumed the presidency on January 1, 2002. His first acts were to end the convertibility scheme, to devalue the peso and to introduce a dual exchange rate, which was changed into a floating rate one month later. All payments of external debt obligations were unilaterally halted.

When the freeze on the bank accounts was partially lifted in February, an unequal sharing of the burden of the devaluation emerged. Dollar loans and deposits were converted to pesos at $1: 1$ and 1:1.4, respectively. With the exchange rate stabilizing at around 3.5 pesos to the dollar, it meant that depositors and lenders recuperated only a third of their previous balances, be it dollars or pesos, with depositors having a slight advantage in the conversion of their dollar accounts. The loss due to the asymmetric treatment of the banks' assets and liabilities estimated to be $\$ 20$ billion were to be covered by government bonds.

Those losses plus the impact of potential government default and increases in non performing assets originating from the modifications of the Bankruptcy Law, were estimated to be about US\$50 billion, which was three times total bank capital of $\$ 17$ billion in mid 2002. In addition to radically alter the legal obligations in the financial sector, the government also negated on the contracts with the mostly foreign private utility companies by imposing price controls on those services. In short, the collapse of the Convertibility Plan provided: a horror scenario for all investors, foreign or domestic, from which it will take time to recuperate (Barham, 2002).

It took time to even achieve the first step, i.e. coming to an agreement with the IMF in early 2003, which made it possible to pay interest and some amounts for amortization of those loans received from the multi-lateral organizations. First steps were also undertaken to restructure the sizeable obligations with foreign private creditors.

In the meantime, social chaos has been avoided. Life is nearly back to normal, and there have been signs of a mild recovery with moderate inflation after the economy hit rock bottom in early 2002. Politics has taken over one more time, as Argentines prepared themselves for another Presidential election in April 2003. For the new President Kirchner a lot of work and a lot of luck will be required to steer the Argentine economy back to the dynamic years of the early1990s. 
The discussion and statistical data presented in this paper have pointed out that while the theoretical framework of a pegged exchange rate regime has a chance to succeed under ideal circumstances, the empirical evidence is littered with casualties. To recollect the theoretical arguments in favor of following a fully pegged exchange rate system, it must be made clear that in addition to the assumption of full flexibility in product and factor markets, guarded by well functioning and alert supervisory and regulatory agencies, the model is completely ignoring politics, which are part and parcel of any development framework.

Critics have pointed out that even the theoretical foundations of the model are questionable. For them, the first problem is the unrealistic "flexibility" assumption, which goes back to the very criticism Keynes raised against the classical school of economics and its automatic micro-and macroeconomic adjustment mechanism.. In this case, the argument is that because of the stickiness of wages and a number of product prices, appreciation of the real exchange rate will occur, killing the goose which is to provide the golden eggs, exports and productive investment.

This brings back the usefulness of the "monetary approach to the balanceofpayments" perceived and practiced by the International Monetary Fund for decades, which is trying to provide sound advice as to how to manage the rapidly changing capital inflows and outflows in an increasing unstable international environment. For the Fund and its friends. the crucial question of the sustainability of a convertibility scheme a la Argentina or a relaxed peg a la Brazil depends first and foremost on what happened in the capital and not the current account of the countries' balance-of-payments, since capital flows have increasingly overtaken trade flows for the last decade and a half.

As Kenen put it succinctly, “[...] to equate appreciation with overvaluation, to treat a current account deficit as a symptom of unsound domestic policies, and thus to regard a capital inflow as a dubious substitute for the elimination of a current account deficit, may have been sensible in the 1970s and 1980s, when capital flows were driven by trade flows" (Kenen, 2001). Looking at the rapidly rising international capital flows in the 1990s, both among the fully industrialized and the emerging economies, it is clear that the paradigm has changed.

The critics would concede that those new developments require a fresh look at the variables most closely linked to the potential inflows and outflows of capital. They share the concern with the "capital balance school" to examine the effects capital inflows have on the quantity and quality of investment and the capacity of future economic growth, but they maintain that a rigorous 
adoption of a convertibility scheme automatically results in at least three very worrisome results, increased macroeconomic instability, disincentives for raising domestic savings and investments, and de-industrialization.

In the first case, the charge is that the former policy induced "stop-and-go" approach is now replaced by an "exogenous shock-stop-and go" dilemma, as occurred in the 1995 and early 1999 crises Argentina encountered. As to domestic savings, the economic literature is unified on the importance of linking efforts to mobilize domestic saving, with productive investment and economic growth (Lewis, 1955; Edwards, 1997). It is a necessary though not sufficient condition for "sustainable development."

Latin American countries have tended to substitute foreign savings and investments whenever it was possible. It is clear that an exchange-rate based development model fortifies the old "growth-cum-debt" model, which has brought so much pain to the populations of the Southern Hemisphere. While policy makers in those countries cannot hide behind high tariff walls and capital controls as they tried in the early post war years, there are better ways of being able to both stimulate domestic saving and investment and benefiting from foreign inflows.

As to the "de-industrialization" debate, another essay will have to do. If the aim is to dismantle an inefficient industrial system by removing tariff and non tariff barriers at the same time as inflation is brought down through a fixed (or quasifixed) exchange rate system, then the most probable outcome is that the export industries are disadvantaged vis-à-vis the import substitution industries, as the remaining inflationary rate will be above the international rate of inflation of the pegged major currency(ies).

In a comparison between "competing" and "protected" firms during Argentina's earlier stabilization-cum liberalization effort between 1976 and 1980, two researchers found that while the competing firms started out with higher profits, they increasingly fared worse than the protected firms, i.e. making higher losses in the last three years of the stabilization program. (Carravallo and Petrei, 1981). The frantic efforts of the Argentine authorities to raise non tariff barriers against such Brazilian industries as steel and shoes in early 1999, only highlights that very problem of exposing perfectly viable industrial firms to the whims of an inflexible exchange rate regime.

If indeed the above criticism is deemed to be valid, what are the alternatives to the very programs evaluated in the paper. There is no comprehensive program, which would fulfill the needs of all Latin American countries, but there is widespread agreements that countries should engage in major efforts to help channel capital inflows into a combination of productive investment and reserves through strengthening of the financial and regulatory system as well as removing either implicit or explicit guarantees for lenders and investors. In that context the careful use of some controls should be exploited. 
This is what the policy makers in Chile and Malaysia did, after they had gone through their financial and currency crises. Although these two economies have shared certain similarities in the past, their current development paths are quite different. Nevertheless, both countries have survived the tumultuous 1990s with less pain than their respective neighbors. Chile used reserve requirements to "control" foreign borrowing, Malaysia put direct controls on capital outflows. Those measures have been evaluated and found wanting (For Chile see Edwards, 2000; for Malaysia see Edison and Reinhart, 2000).

What makes Chile more relevant in thinking about possibilities for the future development in Argentina is the fact that the combination of fiscal, monetary, and structural policies have put that economy on a path which would seem viable at least in the medium run. Talking about the mandatory deposits of short term capital inflows, which Chile introduced in 1992 and gave up in 1998, the Central Bank President maintained that these controls had done their duty, reversing the composition of direct foreign investment to borrowing from $25 / 75$ at the beginning of the decade to $80 / 20$ at the end. "The instrument was necessary when external financing was excessive [...] now the rain has stopped, we decided to close, snap shut, and put away the umbrella." (Fernando-Arias and Hausman, 2000, p. 90) ${ }^{4}$

Not surprising, Chile's strong fiscal position with surpluses in twelve consecutive years played another crucial role in keeping the economy on an even keel. As a consequence, Chile did not need to go out and borrow either in domestic or foreign markets, and leaves the Central Bank the flexibility to raise interest rates in tough times in which foreign capital inflows are desirable without hurting government finances. Last but not least, the Chilean banking system, which had been crashing down in the 1970s, turned out to become the envy of the emerging markets. In 1998, the non-performing loans were $1.2 \%$ of total loans, compared with $8 \%$ in Latin America and over 20\% in Asia.

Even with a sound monetary-fiscal framework like the one Chile had in the late 1990s, external shocks were severe and the sizeable deterioration of the terms of trade required a flexible response, which was made possible through an exchange rate policy, which can be characterized as a managed float with a band. Together with tight monetary policies, the band was narrowed in 1998 to discourage speculators and avoid unnecessary devaluation.

As a country with a relatively small market, Chile had already earlier decided that there was no use to continue with industrial diversification and deepening, Instead, policy makers decided to concentrate on improving and process-

\footnotetext{
${ }^{4}$ In a recent interview, John Williamson, who is considered to be the "father" of the Washington Consensus, maintained that refinements of most of the those earlier proposals are still valid, but he admitted that capital account liberalization had brought with it problems which overwhelmed most of the developing countries; see Barham, (2002).
} 
ing their natural resource industries. By now, Chilean firms have become worldwide exporters not only of copper and ply-wood, but also a whole range of agro-industrial products from frozen fish to quality wines. To help smoothing the substantial fluctuations in world prices of products Chile is absolutely dependent on, like copper and oil, stabilization funds have been instituted, which make it possible for the government to perform its necessary services even in bad times.

It is then no surprise that the very Research Institute, which was once under the direction of Cavallo, invited Chilean politicians and policy makers to Buenos Aires, to discuss with their Argentinian counterparts the usefulness of the Chilean experience for Argentina (Fundacion Mediterranea, 2003). While it became clear that not every feature of one country can be easily reproduced by another one, there was agreement that Chile's flexible and exemplary performance in the monetary and fiscal sectors had great value for future policy making in Argentina.

That conference ended with an assessment of the interaction between politics economics. The Argentine observers of the political scene had to admit that the Chilean democracy, which had emerged after the years of military rule, had recreated a vigorous and lively political system with clear positions on the moderate right and left. In contrast, after 20 years of democracy following military rule in Argentina, the political process was still as volatile and corrupt as it had been in the early post war years, with a strong political parties at the right of the center being nonexistent. A revival of the economy will require a revitalized legal and political system.

\section{REFERENCES}

BARHAM, J. (2002) "Refining the Washington Consensus" Latin Finance, 142.

CARVALLO, D.T. and A.H. PETREI (1981) "Financing Private Business in an Inflationary Context: The Experience of Argentina between 1976 and 1980," IERAL Working Paper, No.6, Fundacion Mediterranea, Cordoba.

DIAZ ALEJANDRO, C. (1980 ou 1981) "Southern Cone Stabilization Plans" in W. Cline and S. Weintraub, eds. Economic Stabilization in Developing Countries. Washington D.C., Brookings, 119148.

EDISON, H.J. and C.M. REINHART (2000) "Capital Controls During Financial Crisis: The Case of Malaysia and Thailand”. International Finance Discussion Paper 662. Washington: Board of Governors of the Federal Reserve System.

EDWARDS, S. (1997) "Why are Latin American Savings so low?” in N. Birdsall and F. Jaspersen, eds.

Pathways to Growth, Comparing East Asia and Latin America. Washington D.C., Inter-American Development Bank, 131-158.

EDWARDS S. (2000) “Exchange Rate Regimes, Capital Flows and Crisis Prevention.” Paper presented to the NBER Conference on Economic and Financial Crisis in Emerging Market Economies, Woodstock, Vt. (October 19-21).

FERRER, A. (1979 ou 1981) “El Monetarismo en Argentina y Chile," Commercio Exterior, (JanuaryFebruary), 176-192. 
FERNANDEZ(Ou Fernando)-ARIAS, E. and R. HAUSMANN (2000) Wanted: World Financial Stability. Inter-American Development Bank, Washington D.C.

Fundacion Mediterranea, IERAL (2002 ou 2003) “Chile 1982-2002 — Leciones para una Argentina en Crisis" Seminar held in Buenos Aires, November December 3.

KENEN, P. (2001) The International Financial Architecture: What's New? What's Missing? Washington D.C., Institute for International Economics.

KUCZYNSKI, P-P. (1992) “International Capital Flows into Latin America: What is the Promise?” World Bank Annual Conference on Development Economics 1992. Washington D.C., The World Bank. LEWIS, W.A. (1955) The Theory of Economic Growth. London, Allen and Unwin.

MALLON R. and J. SOURROUILLE (1975) Economic Policy Making in a Conflict Society: The Argentine Case. Cambridge, Mass.: Harvard University Press.

MESSNER, D. (1996) “Wirtschaftsstrategie im Umbruch: Anmerkungen zu den oekonomischen und politischen Determinanten von Wettnbewerbsfaehigkeit." In D. Nolte and N. Werz. Argentinien. Hamburg, Institut fuer Ibero-Amerika Kunde.

MUSSA, M. (2002) Argentina and the Fund: From Triumph to Tragedy. Washington: Institute for International Economics.

WOGART, J.P. ed. (1983) “Economic Experiments in the Southern Cone, 1974-1982," Journal of Interamercan Studies and World Affairs. 25.4. Miami, Center for Advanced Intenational Studies. WOGART, J.P. (2003) "From the Tablita to the Corralito: Argenhtina's Dilemma with Stabilization Programs," Paper presented at the 24th LASA International Congress. 